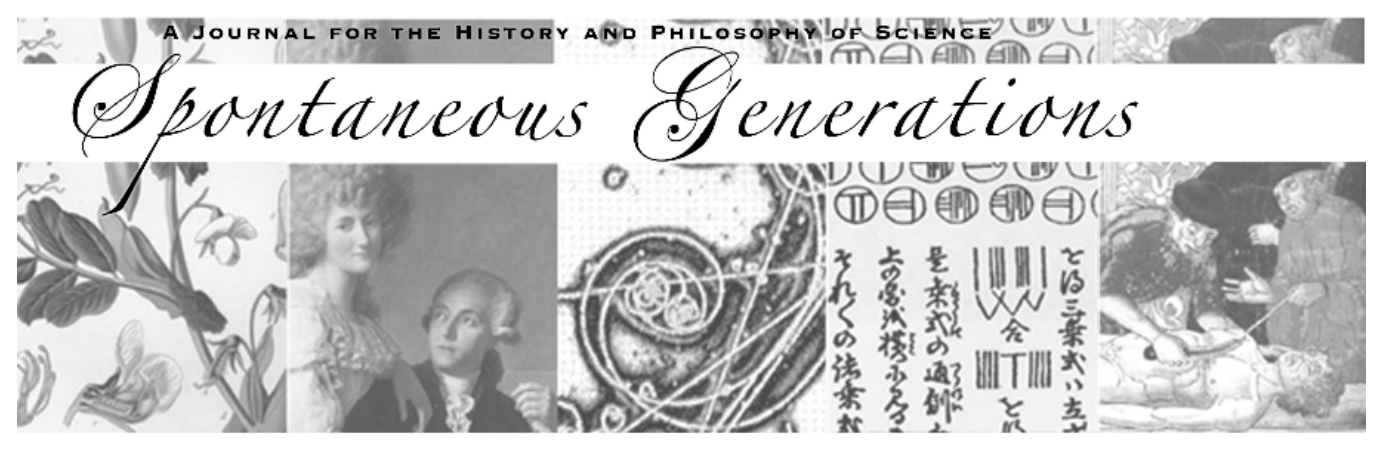

\title{
Thomas Kirke's Copy of Philosophical Transactions
}

Author(s): Sachiko Kusukawa

Source: Spontaneous Generations: A Journal for the History and Philosophy of Science, Vol. 6, No. 1 (2012) 8-14.

Published by: The University of Toronto

DOI: 10.4245 /sponge.v6i1.16374

\section{EDITORIAL OFFICES}

Institute for the History and Philosophy of Science and Technology

Room 316 Victoria College, 91 Charles Street West

Toronto, Ontario, Canada M5S 1K7

hapsat.society@utoronto.ca

Published online at jps.library.utoronto.ca/index.php/SpontaneousGenerations ISSN 19130465

Founded in 2006, Spontaneous Generations is an online academic journal published by graduate students at the Institute for the History and Philosophy of Science and Technology, University of Toronto. There is no subscription or membership fee. Spontaneous Generations provides immediate open access to its content on the principle that making research freely available to the public supports a greater global exchange of knowledge. 


\title{
Thomas Kirke's Copy of Philosophical Transactions*
}

\author{
Sachiko Kusukawa ${ }^{\dagger}$
}

In this paper, I discuss a drawing that substituted for an engraving
in a copy of Philosophical Transactions once owned by Thomas Kirke
(1650-1706, FRS 1693). I suggest that prints allowed Kirke to train his
eye as well as his hand. His case is useful for raising further questions
about visual representations in early modern science.

The Wren Library has a set of Philosophical Transactions once owned by Thomas Kirke (1650-1706). Kirke, from Cookridge, Leeds, matriculated in Trinity College in 1668 (Jackson 2004), though this appears not to be the reason why his set ended up at Trinity. Kirke became part of a circle of like-minded people in York who were interested in the study of natural and antiquarian topics. This group included the physician and naturalist Martin Lister (1639-1712) (Roos 2011), the antiquarian Ralph Thoresby (1658-1728) (Kell 2004) and the glass-painter Henry Gyles (1646-1709) (Brighton 2004). Kirke was elected Fellow of the Royal Society on 30 November 1693, became a close friend of Sir Godfrey Copley's (1653-1709), and was known for his fine library, a museum, and a park with a maze (Armytage 1954).

We do not know when Kirke started to subscribe to Philosophical Transactions, but a full set of volumes 1 to 22 have survived. Kirke marked the title page of every volume with his monograph "TK." He seems to have read through every issue of the journal, assiduously implementing the corrections listed in the errata at the back, and inscribing now and again names of authors of papers whose names had not been printed. At one place on page 629 in issue

* Received 7 March 2012

$\dagger$ Sachiko Kusukawa is Tutor and Fellow at Trinity College, Cambridge and Research Fellow at the Centre for Arts and Humanities Research in the Natural History Museum, London. Her recent research has focused on the observational, descriptive, and pictorial practices in the development and production of scientific knowledge in the early modern period (1500-1720). Her book, Picturing the book of nature: image, text, and argument in sixteenth-century human anatomy and medical botany, (Chicago: University of Chicago Press), has been published this year. Other recent publications include: Picturing Knowledge in the Early Royal Society: The Examples of Richard Waller and Henry Hunt, Notes and Records of the Royal Society 65 (2011): 273-94; Patron's Review: The Role of Images in the Development of Renaissance Natural History, Archives of Natural History 38(2) (2011): 189-213; and The Sources of Gessner's Pictures for the Historia Animalium, Annals of Science 67(3) (2010): 303-28.

Spontaneous Generations 6:1 (2012) ISSN 1913-0465. University of Toronto. 


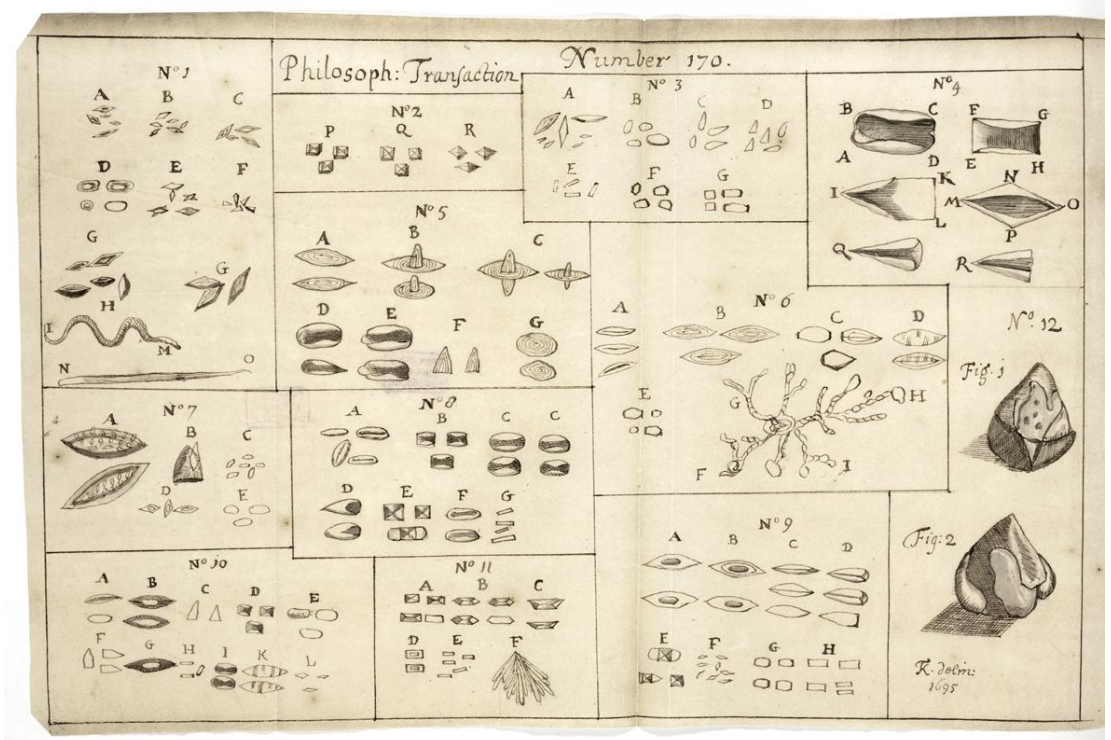

Figure 1. Thomas Kirke. Kirke's drawing of the engraving for no. 170 of Philosophical Transactions. By kind permission of the Master and Fellows of Trinity College, Cambridge.

no. 33 (1667/8), he inscribed a proverb, "nulla dies sine linea [no day without a line]," which was associated with the most famous painter of antiquity, Apelles. The latter was reputed to have practised daily at his craft, however busy he was (Pliny the Elder, 1938-1963, IX, 323).

No. 170 of Philosophical Transactions, dated 20 April 1685, was printed in Oxford. Since Henry Oldenburg's time, the publication of this journal, including the financial arrangements, was the personal responsibility of the Secretary of the Royal Society (Andrade 1965). While Francis Aston (1644-1715) was Secretary, Philosophical Transactions (no. 144 to no. 178) was printed in Oxford, because the printing of both the text and engravings was deemed "better and cheaper" there (Gunther 1939, 368). Aston, in London, sent up papers and drawings to Oxford where Robert Plot (1640-96), followed by William Musgrave (1655-1721), supervised their printing. No. 170 contained an engraving divided into 12 boxes. Figures in the first eleven boxes were of salts observed by Antoni van Leeuwenhoek (1632-1723) in vinegar and in wines from different parts of Europe and the twelfth box showed stones voided by stool by a carpenter from Halifax. Aston wrote to Musgrave on 26 March 1685:

I think to send you to-morrow a letter of Mr Leewenhoeck about the figures of Salts, there are some things in it very curious, there are 11 plates of figures, which perhaps will goe into one ordinary plate, but if they will not, or if you have more Figures, I would have you make 2 plates, for wee ought never to make a plate too big. (quoted in Gunther 1939, 85-86) 
The drawings were thus sent up to Oxford and engraved onto one plate with just one additional figure for the issue.

In Kirke's copy (Figure 1), the engraving is replaced by a drawing by him. At the bottom right of the page where the engraving was marked "I.S. sculp.," Kirke had inscribed: "TK delin: 1695" to indicate that TK drew [this in] 1695.

Why did Kirke make this drawing? A plausible answer would be that when Kirke decided to obtain a full run of the Philosophical Transactions, he found the engraving lacking or mangled in this particular issue, but managed to borrow one from someone else to copy. We unfortunately know very little about how back issues and engravings were acquired by later readers to complete a set. It is not obvious that it was the subject-matter that led Kirke to copy the engraving, since there is another drawing by Kirke for issue no. 195, which illustrates entirely unrelated topics. It seems unlikely that Kirke deliberately removed these two engravings to substitute them with his own drawings.

Kirke's drawing for no. 170 is in fact a remarkably faithful line-drawing copy of the original engraving, including the hatching in the shadows. It is rare that we find evidence of the graphic skills of a Fellow of the Royal Society-and it is even rarer to work out how such a person might have become a proficient draughtsman. In Kirke's case, we have two clues. The first is a letter he wrote on 20 June 1674, from London to Henry Gyles in York:

Honest Harry ... you advise mee to gett A collection of good prints \& you animate mee to it by Mr Bells example; I confesse I love prints and could wish that I were well stokt with them: but (res angusta domi) will not suffer mee to lye out any thing excepting for absolute necessities. You say Mr Lodge will see mee as soone as hee comes to Towne. I shall be glad to see him \& I will goe along with him (as I have done with Mr Addinall) to see him chuse good things that I may better my judgement that way by him. I find the cattalouge of good Cutts in my Trunk which I shall peruse. (quoted in Hake 1922, 62)

"Mr Lodge" is most certainly William Lodge of Leeds (1649-89) (Griffiths 2004b), who went on to produce etchings in Giacomo Barri's The Painter's Voyage of Italy (1679). Mr Addinall could be a William Addinall recorded as a painter, stainer, and freeman of York in 1688 (Collins 1900, 166). Kirke's acquaintances from Yorkshire certainly shared an interest in collecting prints and were guiding him in what to collect and how to go about collecting them. Kirke's letter is an indication of how he trained his eye and judgment for good prints by following others' advice and example.

Kirke also reported in the same letter that he met Joseph Moxon (1627-91), printer, globe-maker, and author of Practical Perspective: or Perspective Made Easie (1670) (Bryden 2004) and through him, William Faithorne the Elder 
(1616-91), the pastellist and engraver who had published The Art of Graveing and Etching (1662) (Griffiths 2004a).

I mett Mr Moxon there who writt of a peece of perspective (which you have of mine) \& wee went to Mr Faithorne the engraver \& drunk a glass of wine with him and A friend of his A young painter I suppose. Mr Moxon and Mr Faithorne were att high words whether the true knowledge of perspective was absolutely necessary for A painter or noe. Mr Moxon affirmed it was \& Mr Faithorne denied it, till at length Mr Faithorne told Mr Moxon he needed not defend it soe highly for the booke he writte of it was but A translation etc. (quoted in Hake 1922, 63)

Kirke kept company with authors of recent books on the graphic arts who were craftsmen with links to the Royal Society. Moxon would soon become a Fellow of the Royal Society (1678) and Faithorne had connections with Fellows such as Samuel Pepys (1633-1703), Robert Hooke (1635-1703), and Edward Tyson (1651-1708). This letter suggests that Kirke was not just learning empirically about good prints from his Yorkshire friends, but that he was also party to more general discussions about the usefulness of perspective.

The second clue comes from a manuscript that Kirke once owned, entitled The Art of limning ether by the life landscape or histories, now MS 33 at the Yorkshire Archaeological Society, Leeds. This happens to be a very close (though incomplete) copy of Edward Norgate's Miniatura, or, the Art of Limning, whose initial owners were "an elite and interlocked society which kept to itself the secret of limning incorporated in Norgate's text" (Norgate 1997, 15). Kirke's manuscript is almost identical to the manuscript now in the British Library, Harleian 6376, compiled soon after Anthony Van Dyck's death in 1641 (Norgate 1997, 221) by the miniaturist John Hoskins (Murdoch 2004). By 1679, this manuscript was owned by Henry Gyles, and it is very likely that Kirke borrowed this copy from Gyles to make his own.

Harleian 6376 and Kirke's copy are variations of the first version of Norgate's Miniatura and start with a detailed account of drawing implements and the importance of training to draw (Norgate 1997, 208-302). This is a section that was not present or prominent in Norgate's second version, nor was it included in William Sanderson's publication of Graphice (1658) which drew on the first edition (Norgate 1997, 223). Kirke's manuscript explains how to master the art of drawing, expressed as an ability to copy a print faithfully: "Limn not at all before you can Imitate a print of Albert Durer or some other Master, soe well as the one may hardly be knowne from the other with a penn" (Kirke n.d., 3v). It advised "dayly practice," of first copying a simple print or a discrete part of a print such as a bird, face, or hand, before moving on to wax models and then eventually drawing objects "by the life." It then promoted drawing from memory 
which would assist the imagination, judgement, and invention. For my present purposes, the point to note about Kirke's manuscript is how prints were used as the starting point for learning to draw. The lines in prints were to be copied first with chalk, the draft had to be compared with the print and corrected, and the use of a compass was recommended for checking the proportions of the component parts. The chalk lines were then rubbed out lightly and traced over with finer lines using a pen made of a quill of a raven or a goose, and shadows were added with hatching (Kirke n.d., 3v-4r).

Without studying Kirke's library in detail or without understanding the circulation of other drawing manuals, it would be rash to claim any well-defined interest in Norgate's Miniatura among the Fellows of the Royal Society or among the York group. It would be tempting, nevertheless, to think that Kirke had trained his hand by copying prints as advocated in a Norgate manuscript, practising daily, perhaps, as the Elder Pliny claimed Apelles had done. Kirke's drawing of the engraving of Philosophical Transactions certainly shows that he was capable of copying a print faithfully. Kirke, in fact, appears to have been not alone in copying prints, since we know that his friend Thoresby (who also owned a Norgate manuscript, now MS Add. 12461, British Library), for example, copied engravings in Gilbert Burnet's History of the Reformation of the Church of England (Hunter 1830, I, 113). For the moment, we can note that for Kirke, prints were important for training both the eye and the hand.

While the specifics of Kirke's training as a draughtsman remains conjectural, his case prompts us to wonder how Fellows of the Royal Society like Kirke, whose eyes and hands were trained by prints, appreciated and judged other printed images in scientific books or journals, and how their training, in turn, affected the way they themselves put images to use in matters of knowledge. Studies of the uses of drawings in natural knowledge and of the editorial processes of transforming images into printable and printed form would undoubtedly contribute to our understanding of visual representations in the Royal Society, but these are yet to be undertaken in any comprehensive way. Without better insight into the graphic ideals, skills, and practices of those who were interested in studying nature, we are not yet in a position to determine whether there was a genre of visual representations that was specifically "scientific" in the early modern period.

\author{
SaCHIKo Kusukawa \\ Trinity College \\ Cambridge CB2 1TQ \\ United Kingdom \\ sk111@cam.ac.uk
}




\section{REFERENCES}

Andrade, Edward N. da C. 1965. The Birth and Early Days of the Philosophical Transactions. Notes and Records of the Royal Society of London 20(1) (June): 9-27.

Armytage, Walter H. G. 1954. Sir Godfrey Copley, F.R.S. 1543-1709: Some Tercentenary Glimpses through Letters to his Friends. Notes and Records of the Royal Society of London 11(1) (January): 54-74.

Brighton, Trevor. 2004. Gyles, Henry (bap. 1646, d. 1709). In Oxford Dictionary of National Biography. Oxford: Oxford University Press.

www.oxforddnb.com/view/article/11824

Bryden, David J. 2004. Moxon, Joseph (1627-1691). In Oxford Dictionary of National Biography. Oxford: Oxford University Press. www.oxforddnb.com/view/article/19466

Collins, Francis. 1900. Register of the Freemen of the City of York from the City Records. Vol. 2: 1559-1759. Durham: Andrew.

Griffiths, Antony. 2004a. Faithorne, William (c.1620-1691). In Oxford Dictionary of National Biography. Oxford: Oxford University Press. www.oxforddnb.com/view/article/9102

Griffiths, Antony. 2004b. Lodge, William (1649-1689). In Oxford Dictionary of National Biography. Oxford: Oxford University Press. www.oxforddnb.com/view/article/16924

Gunther, Robert T. 1939. Dr Plot and the Correspondence of the Philosophical Society of Oxford. Vol. 12 of Early Science in Oxford. Oxford: R. T. Gunther.

Hake, Henry M., ed. 1902. Some Contemporary Records relating to Francis Place, with a Catalogue of his Engraved Work. Vol. 10 of The Walpole Society Publications. London: The Walpole Society.

Hunter, John. 1830. The Diary of Ralph Thorseby, FRS. Author of the Topography of Leeds (1677-1734). 2 vols. London: H. Colburn and R. Bentley.

Jackson, Clare. 2004. Kirke, Thomas (1650-1706). In Oxford Dictionary of National Biography. Oxford: Oxford University Press. www.oxforddnb.com/view/article/15666

Kell, P.E. 2004. Thoresby, Ralph (1658-1725). In Oxford Dictionary of National Biography. Oxford: Oxford University Press. www.oxforddnb.com/view/article/27334

Kirke, Thomas. n.d. The Art of limning ether by the life landscape or histories, [MS 33, Yorkshire Archaeological Society, Leeds].

Murdoch, John E. 2004. Hoskins, John (c.1590-1665). In Oxford Dictionary of National Biography. Oxford: Oxford University Press. www.oxforddnb.com/view/article/13839

Norgate, Edward. 1997. Miniatura or the Art of Limning. eds. J. M. Muller and J. Murrell. New Haven: Yale University Press.

Pliny the Elder. 1938-1963. Natural History. Trans. H. Rackham, W. H. S. Jones, and D. E. Eichholz. 10 vols, Loeb classical library. London: Heinemann. 
S. Kusukawa Thomas Kirke’s Copy of Philosophical Transactions

Roos, Anna Marie. 2011. Web of Nature: Martin Lister (1639-1712), the First Arachnologist. Leiden: Brill. 